\title{
IMPLEMENTASI KEBIJAKAN DANA DESA \\ DALAM MENINGKATAN PEMBANGUNAN DI DESA WUKIRSARI, KABUPATEN SLEMAN
}

\author{
Fransisca Winarni $^{1}$ dan Pandhu Yuanjaya ${ }^{2}$
}

\begin{abstract}
This study aims to determine the implementation of the Village Funds as an effort to increase rural development in the village Wukirsari Cangkringan Sleman. The research approach used in this research was descriptive qualitative. Techniques of data retrieval were done through observation, interview, and review of documentation. Data analysis technique used interactive analysis techniques adopted from Mills and Huberman. Rnenunjukkan research results that the policy implementation using village funds under Regulation 60 Year 2016 Wukirsari village crushing implemented. The result of the development of the use of village funds was used for infrastruscture development. The success of the policy implementation due to factors of good communication, the resources both human capacity and adequate funding, clear and coordinated bureaucratic structure, and good commitment and integrated bureaucratic disposition to the success of rural development in Wukirsari.
\end{abstract}

Keyword: Village Funds, Rural Development, Policy Implementation

\begin{abstract}
ABSTRAK
Penelitian ini bertujuan mengetahui implementasi Dana Desa sebagai upaya peningkatan pembangunan desa di desa Wukirsari Kecamatan Cangkringan Kabupaten Sleman. Pendekatan penelitian yang digunakan dalam penelitian ini adalah deskriptif kualitatif. Teknik pengambilan data dilakukan melalui obeservasi, wawancara dan telaah dokumentasi. Teknik analisis data digunakan teknik anaiisis interaktif yang diadopsi dari Mills dan Huberman. Hasil penelitian rnenunjukkan bahwa implementasi kebijakan penggunaan dana desa berdasarkan PP 60 rahun 2016 di desa Wukirsari telak dilaksanakan dengan baik. Hasil pembangunan dari penggunaan dana desa dimanfaatkan untuk pernbangunan fisik. Keberhasilan Implementasi kebijakan tersebut karena faktor-faktor komunikasi yang baik, adanya sumberdaya baik kapasitas aparatur maupun dana yang cukup, struktur birokrasi yang jelas dan terkoordinasi dan adanya disposisi birokrasi yang memiliki komitmen dan integritas untuk meningkatkan pembangunan desa.
\end{abstract}

Kata Kunci: Dana Desa, Pembangunan Desa, Implementasi Kebijakan

1,2 Dosen, Jurusan Ilmu Administrasi Negara, Universitas Negeri Yogyakarta. email: francisca_winarni@uny.ac.id dan pandhu@uny.ac.id 


\section{PENDAHULUAN}

Pembangunan desa selama ini menjadi salah satu topik yang kerap hanya disinggung dalam pembahasan mengenai praktek otonomi daerah di Indonesia. Padahal, tujuan utama pembangunan yaitu meningkatkan distribusi pembangunan dan program lainnya pada wilayah pedesaan (Hehamahua, 2015). Artinya, wilayah pedesaan adalah subjek pembangunan, yang bertumpu pada paradigma bahwa esensi otonomi daerah mewujudkan kemandirian daerah melalui penguatan potensi lokal. Tentu perspektif tersebut akan sangat berarti karena dijalankan oleh lebih dari $60 \%$ penduduk Indonesia yang tinggal di pedesaan (Data Sensus Badan Pusat Statistik (BPS), 2010). Dalam kenyataannya, pembangunan dari desa hingga saat ini cenderung hanya dijadikan retorika politik dan komoditas berbagai kepentingan dalam pemilu, dari pada upaya nyata untuk mewujudkannya. Implikasinya jelas, walaupun dalam undang-undang titik berat otonomi daerah lebih diletakkan pada tingkat Kabupaten/Kota, sesungguhnya tidak dapat dilakukan tanpa terlebih dahulu mengupayakan pembangunan desa, baik masyarakat maupun pemerintahan di desa yang selama ini belum berjalan dengan baik.
Pengesahan Undang-Undang Nomor 6 Tahun 2014 tentang Desa membawa euforia tersendiri bagi para pemangku kepentingan desa. Dengan UU tersebut, pengaturan tentang desa mengalami perubahan secara signifikan. Dari sisi regulasi, desa tidak lagi menjadi bagian dari UU Nomor 23 tahun 2014 tentang Pemerintahan Daerah. Desa-desa di Indonesia akan mengalami reposisi dan pendekatan baru dalam pelaksanaan pembangunan dan tata kelola pemerintah desa. UU tersebut memberikan kewenangan luas kepada desa dibidang penyelenggaraan pemerintahan desa, pelaksanaan pembangunan desa, pembinaan kemasyarakatan desa, dan pemberdayaan masyarakat desa berdasarkan prakarsa masyarakat, hak asal usul, dan adat istiadat desa. Dengan kata lain, desa ditempatkan sebagai suatu organisasi pemerintahan yang secara politis memiliki kewenangan tertentu untuk mengurus dan mengatur warga atau komunitasnya.

Posisi pemerintah desa dalam pembangunan nasional dan regional merupakan bagian yang tidak terpisahkan dari pembangunan pedesaan dimana mayoritas penduduk tinggal. Desa juga adalah basis kekuatan dari sosial, ekonomi 
dan politik yang memerlukan perhatian serius dari pemerintah. Disisi lain, konstruksi nyata dalam sebuah desa terbentuk dari alokasi dana untuk desa. Alokasi dana desa tersebut memberikan desa persamaan kemampuan pendanaan yang proporsional dari pemerintah pusat dan daerah. Alokasi dana desa adalah bentuk dari pemenuhan hak desa untuk mengimplementasikan otonomi utnuk tumbuh dan berkembang berdasar dari kekhasan, partisipasi, pemberdayaan, dan demokrasi masyarakat dan pengembangan peraturan dari pemrintah desa dalam penyediaan pelayanan dan peningkatan kesejahteraan masyarakat. Melalui alokasi dana untuk desa, desa memiliki kesempatan untuk mengatur pembangunan, pemerintahan dan pembangunan sosial dengan mandiri.

UU Desa memberi jaminan yang lebih pasti bahwa setiap desa akan menerima dana dari pemerintah melalui anggaran negara dan daerah yang jumlahnya berlipat, jauh diatas jumlah yang selama ini tersedia dalam anggaran desa, yang disebut dengan Dana Desa. Alokasi anggaran tersebut kemudin diatur dalam Peraturan Pemerintah No. 60 Tahun 2014 tentang Dana Desa yang Bersumber dari Anggaran Pendapatan dan Belanja Negara (APBN). Tersedianya proporsi anggaran yang memadai tersebut merupakan konsekuensi logis seiring reposisi desa sebagai fokus utama pembangunan. Wasistiono menyatakan bahwa pembiayaan atau keuangan merupakan faktor essensial dalam mendukung penyelenggaraan pembangunan desa. Oleh karena itu, penggunaan Dana Desa dapat memenuhi kebutuhan pembangunan dan pemberdayaan masyarakat desa.

PP Dana Desa mengatur tiap kabupaten wajib mengalokasikannya ke pada setiap desa berdasarkan jumlah desa dengan memperhatikan jumlah penduduk (30\%), luas wilayah (20\%), dan angka kemiskinan (50\%). Hasil perhitungan tersebut disesuaikan juga dengan tingkat kesulitan geografis masing-masing desa. Besaran alokasi anggaran yang peruntukannya langsung ke Desa ditentukan $10 \%$ dari dan di luar dana Transfer Daerah (on top) secara bertahap. Penyaluran Dana Desa dilakukan melalui mekanisme transfer ke APBD kabupaten/kota untuk selanjutnya ditransfer ke rekening kas desa dalam tiga tahap penyaluran. Tahap I dan II disalurkan pada bulan April dan Agustus masing-masing sebesar 40 persen, dan tahap III sebesar 20 persen pada bulan Nopember. 


\begin{tabular}{|c|c|}
\hline \multirow{3}{*}{\begin{tabular}{lcr}
\multicolumn{1}{c}{ Kebijakan } & ini & memiliki \\
konsekuensi & terhadap & proses \\
pengelolaannya & yang & seharusnya
\end{tabular}} & 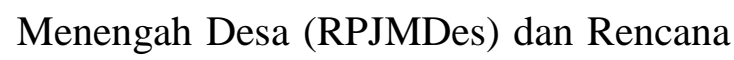 \\
\hline & Kerja Pemerintah Desa (RKPDes) yang \\
\hline & nenjadi prasyarat dalam pencairan dana \\
\hline & \\
\hline an efisien, serta akuntabel yang & dikeluarkan oleh \\
\hline lidasarkan pada prinsip-prinsip & Wukirsari adalah jumlah kegia \\
\hline nanejemen publik yang baik agar & pemberdayaan masyarakat yang mini \\
\hline terhindarkan dari resiko terjadinya & Padahal, de \\
\hline enyimpangan, penyelewengan dan & pemberdayaan \\
\hline orupsi. Dari jumlah desa di Indones & memperkuat \\
\hline ebanyak /2.944 aesa, & ekonomi lokal dan \\
\hline nyak pe & masyarakat \\
\hline engelola APBDes & \\
\hline
\end{tabular}
rupiah secara akuntabel dan transparan (KPK, 2015). Oleh karenanya, penting dilakukan studi mendalam mengenai ilmplementasi kebijakan penggunaan Dana Desa dalam upaya pembangunan desa di Desa Wukirsari, Kecamatan Cangkringan, Kabupaten Sleman.

Penggunaan Dana Desa di Desa Wukirsari dipakai untuk pembangunan infrastruktur desa dan memperkuat Badan Usaha Milik Desa (BUMDes). Pembangunan infrastruktur tersbeut misalnya seperti bendungan desa yang akan di manfaatkan untuk memnuhi kebutuhan irigasi desa. Total penyerapan anggaran di Desa Wukirsari tahun 2015 mencapai 100 persen sesuai perencanaan awal. Desa Wukirsari juga mampu membuat Rencana Pembangunan Jangka

\section{METODE}

Penelitian ini mengunakan pendekatan kualitatif dengan metode deskriptif. Penelitian kualitatif dapat digunakan untuk mengungkap dan memahami sesuatu di balik fenomena (Moleong, 2004; Strauss dan Corbin, 2007; Creswell, 2010). Penelitian ini dilakukan di Desa Wukirsari, Kecamatan Cangkringan, Kabupaten Sleman. Pemilihan lokasi penelitian berdasarkan observasi awal dengan berkunjung langsung dan rilis dokumen dari Kementerian Desa, Wilayah Tertinggal dan Transmigrasi yang menempatkan Desa Wukirsari sebagai Desa berhasil mengelola Dana Desa. 
Informan penelitian adalah orang yang dianggap mengetahui informasi dan masalah secara mendalam tentang obyek penelitian dan dapat dipercaya sebagai sumber data yang mantap (purposive) (Sutopo 2002). Dalam penelitian ini yang menjadi informan adalah Kepala Desa, Sekertaris Desa, Kepala Dusun, Masyarakat Desa, Bagian Pemberdayaan Desa Kecamatan. Untuk memperoleh data dan informan yang tepat dalam penelitian ini diperlukan teknik dan alat pengumpulan data dengan observasi, wawancara, telaah dokumentasi berdasarkan Yin (2003). Metode analisis dalam penelitian ini menggunakan model analisis interaktif (Miles dan Huberman, 1992).

\section{HASIL DAN PEMBAHASAN}

\section{Deskripsi Lokasi Penelitian}

Desa Wukirasari merupakan salah satu desa yang terletak di Kecamatan Cangkringan Kabupaten Sleman.

Penduduk Desa Wukirsari hingga tahun 2014 mencapai 10.930 jiwa. Dari total jumlah penduduk Desa Wukirsari menurut jenis kelamin dengan jumlah 5.518 perempuan dan 5.412 laki-laki. Berdasarkan data jenis mata pencaharian penduduk Desa Wukirsari, petani menjadi profesi mayoritas sebesar 2.315 orang atau
$21,18 \%$, selain itu terdapat $4,01 \%$ atau sebesar 438 orang berprofesi sebagai buruh tani. Selain pertanian, masyarakat di Desa Wukirsari yang berprofesi sebagai pegawai swasta cukup besar yaitu $11,93 \%$ atau sebesar 1.304 orang, diikuti wiraswasta sebesar 369 orang atau $6,86 \%$, pertukangan 5, 24\% dan berturut-turut berprofesi PNS, TNI, POLRI, serta pekerjaan lainnya (informal) sebesar $13,26 \%$.

Apabila dilihat berdasarkan tahapan keluarga sejahtera yang dikembangkan oleh Badan Kependudukan dan Keluarga Berecana Nasional (BKKBN), penduduk Desa Wukirsari dapat diklasifikasikan dalam beberapa klasifikasi yaitu, Keluarga Pra Sejahtera sebanyak 747 KK, Keluarga Sejahtera 1 sebanyak 972 KK, Keluraga Sejahtera 2 sebanyak 342 KK, Keluarga Sejahtera 3 sebanyak 704 KK, Keluarga Sejahtera Plus sebanyak 190 KK. Klasifikasi tersebut menunjukkan jumlah yang keluarga sangat miskin dan miskin (diasosiasikan dengan Kelurga Prasejahtera dan Keluarga Sejahtera 1), jumlahnya lebih besar dibandingkan dengan keluarga dalam klasifikasi Keluarga Sejahtera 2, 3 dan Plus. 
Sebagai salah satu desa yang menjadi akses ke wilayah wisata kaliurang dan desa terdampak potensi Bencana Gunung Merapi (PVMBG, 2010), sarana jalan sepanjang $52 \mathrm{~km}$ dan sebanyak 12 jembatan di Desa Wukirsari cukup baik. Pemenuhan kebutuhan lisrik dipenuhi oleh PT PLN (Persero) yang melayani 3.170 pelanggan dan seluruh Padukuhan di Desa Wukirsari telah tersedia jaringan listrik. Ruas jalan terutama yang melintasi wilayah pemukiman telah tersedia penerangan jalan baik sambungan dari rumah maupun pemasangan Lampu Penerangan Jalan Umum oleh Dinas Kimpraswil Kabupaten Sleman. Sarana telekomunikasi secara umum tersedia luar di Desa Wukirsari karena letaknya cukup strategis baik sebagai daerah berkembang maupun statusnya sebagai desa terdampak bencana Gunung Merapi. Sarana di Desa Wukirsari dengan kondisi demikian juga merupakan wujud sebagai salah satu Desa Tangguh Bencana di Kabupaten Sleman.

Potensi ekonomi di Desa Wukirsari cukup beragam diantaranya terdapat industri rumah tangga seperti kerajinan batu, makanan olahan, perdagangan, peternakan, perikanan dan lainnya. Pertanian adalah penyokong utama kehidupan warga Desa Wukirsari (seperti yang dijelasan dalam Table 4.2).
Potensi pertanian yang terdapat di Desa Wukirsari yaitu pertanian padi, salak pondoh, pertanian sayuran dan beberapa komoditas lainnya. Kerajinan Batu yang ada adalah pembuatan peralatan rumah tangga yang berada di wilayah Padukuhan Plupuh dan Padukuhan Bulak Salak. Hasil dari kerajinan batu tersebut dipasarkan hingga ke luar kota. Berdasarkan hasil observasi, seluruh pengrajin tersebut menggunakan alat mekanik modern seperti mesin bubut, gergaji mesin khusus untuk batu, dan lain sebagainya. Kerajinan ini masih eksis mengingat potensi pasar cukup besar terutama wilayah DIY dan sekitaranya.

Potensi peternakan di Desa Wukirsari cukup besar mengingat hampir seluruh masyarakat memiliki peternakan (berbagai skala usaha) seperti ternak sapi, kambing, dan ayam (wawancara dengan Kepala Desa Wukirsari, 24 Oktober 2016). Meskipun peternakan menjadi salah satu sumber ekonomi yang cukup menjanjikan, hanya beberapa keluarga saja yang melakukan pelolahan hasil peternakan untuk meningkatkan nilai dari produk. Selebihnya, ternak hanya sebagai pekerjaan sampingan. Selain itu, terdapat peternakan yang dibudidayakan dan dengan pengelolaan khusus yaitu ternak ayam potong yang ada di Padukuhan 
Karangpakis. Usaha budidaya perikanan ini difokuskan pada pembesaran bibit ikan dan dijual ketika sudah mencapai ukuran standar untuk dikonsumsi. Disampim pembesaran bibit saat ini petani ikan juga telah mengembangkan pembibitan. Jenis ikan yang banyak dipelihara adalah Gurame, Mas, Nila, Patin, Grescap, Lele Dumbo dan Ikan Hias.

\section{Implementasi Penggunaan Dana Desa}

Implementasi kebijakan

Penggunaan Dana Desa di Desa Wukirsari

dilihat dari empat aspek yaitu: komunikasi, sumberdaya, strukur birokrasi dan disposisi (Edward III, 1980). Uraian keempat aspek tersebut dijelaskan sebagai berikut:

\section{Komunikasi}

Implementasi kebijakan ini diawali dengan proses sosialisasi yang merupakan proses komunikasi kebijakan. Kegiatan sosialisasi ini bertujuan untuk memberikan informasi yang jelas kepada masyarakat desa dan perangkat desa tentang adanya kebijakan yang berkaitan dengan sumber pendanaan baru bagi pemerintah desa dalam menyelenggarakan pemerintahan dan pembangunan di tingkat desa. Kegiatan tersebut dilakukan dalam musyawarah desa yang menjadi forum komunikasi antar masyarakat dan pemerintah desa. Musyawarah desa biasanya dilakukan terkait adanya program baru yang mendesak untuk diputuskan bersama. Hal ini dilakukan untuk menghindari adanya tumpang tindih informasi yang diterima oleh masyarakat desa terkait Dana Desa yang cenderung mendiskreditkan pemerintah desa. Hal ini tentu saja akan menimbulkan ketidakpercayaan masyarakat terhadap pemerintah desa. Selain itu masyarakat juga masih belum memahami secara menyeluruh tentang dana desa yang diterima oleh pemerintah desa.

Musyawarah diselenggarakan oleh masyarakat bersama BPD, LPMD dan perangkat desa. Dalam kegiatan tersebut dilakukan perundingan bersama mengenai kebijakan-kebijakan yang akan diambil dengan memperhatikan prioritas kebijakan terutama RPJMDes. Musyawarah penggunaan dana desa di Wukirsari melibatkan masyarakat secara penuh. Sehingga menurut sekretaris Desa Wukirsari tidak ada konflik antar aktor dalam pengimplementasian kebijakan penggunaan dana desa ini. Karena kebijakan penggunaan dana desa yang telah disepakati mampu merepresentasikan

kepentingan- 
kepentingan seluruh masyarakat desa. Sekretaris desa juga menambahkan bahwa keberhasilan dari implementasi kebijakan penggunaan dana desa ini berasal dari proses perencanaan yang baik tepat dan strategis.

Kepala Desa di Desa Wukirsari juga menjadi salah satu kunci, apabila tidak dapat dikatakan satu-satunya, keberhasilan komunikasi penggunaan dana desa. Pendekatan personal kepada tokoh-tokoh masyarakat oleh kepala daerah menjadi kunci tidak adanya resistensi terkait penggunaan Dana Desa yang diajukan oleh pemerintah desa. Legitimasi yang tinggi kepada lurah menjadi penyebab dalam implementasi program masyarakat cenderung hanya mengikuti secara pasif.

\section{Sumber daya}

Sumberdaya dalam implementasi kebijakan dapat kelompokkan dalam beberapa sumberdaya seperti: manusia, dan dana. Dana Desa memberikan ruang fiskal yang lebih besar bagi pemerintah desa. Dana Desa (DD) Semester I Tahun 2016 saja berjumlah Rp.762.527.000,00. Anggaran Pagu Dana Desa tersebut meningkat dua kali lipat apabila dibandingkan dengan Anggaran Dana Desa Tahun 2015 berjumlah
Rp.331.965.000. Penggunaan Dana Desa (DD) yang diperuntukan bagi kegiatan pembangunan dan pemberdayaan. Namun hingga saat ini $100 \%$ digunakan untuk Pelaksanaan Pembangunan Desa untuk penunjang kegiatan Pembangunan Talud jalan Usaha Tani dan Gorong-gorong. Selain itu dipergunakan untuk Bidang Pembinaan Kemasyarakatan dan Pemberdayaan Masyarakat.

Implementasi kebijakan penggunaan dana desa juga tidak terlepas dari sumberdaya yang berupa sumberdaya manusia yang dimiliki oleh desa wukirsari dan kapasitas kelembagaan yang ada di desa Wukirsari. Pegawai pemerintah desa Wukirsari sejumlah 38 orang, yang terdiri dari Kepala Desa, Sekertaris Desa, beberapa Kepala Bagian, Staff, Tenaga Kontrak, serta Dukuh dari beberapa padukuhan.

Dari jumlah tersebut dilihat dari tingkat pemahaman pegawai pemerintah desa terhadap pengelolaan dana desa masih cukup beragam. Mayoritas dari pegawai hanya memahami dana desa sebatas pada hal-hal dasar yang dianggap perlu. Pernyataan Sekertaris Desa Wukirsari tersebut mempertegas pemahaman dari pegawai pemerintah desa terhadap dana desa masih beragam dan 
belum mendalam. Mayoritas pegawai pemerintah desa Wukirsari berlatar belakang pendidikan SLTA atau sederajat. Namun hal tersebut tidak menjadi faktor penghambat pemerintah desa wukirsari dalam pengelolaan dana desa nya. Menurut sudut pandang pegawai pemerintahan desa, pemerintah desa wukirsari telah mampu mengelola dana desa yang diterimanya.

\section{Struktur Birokrasi}

Strukur birokrasi yang tersedia di Desa Wukirsari telah memiliki bagian yang telah spesifik mengengola suatu urusan. Selain itu kemampuan tiap pegawainya pun sudah cukup memadai walaupun dari latar belakang yang berbeda, sehingga tidak menjadi penghambat dalam pengelolaan dana desa.

$$
\text { Pelaksanaan penggunaan Dana }
$$

Desa di Wukirsari Kec. Cangkringan Sleman, maka pengelola Dana Desa (DD) tidak terlepas dari peran Aparatur Desa, BPD, LPMD, TPK, Tokoh masyarakat, padukuhan, masyarakat Wukirsasri. Dalam pengelolaan dan pengimplementasian dana desa melibatkan beberapa stakeholder sesuai dengan peran dan bidangnya yaitu sebagai berikut: a. Perangkat Desa

$$
\text { Pengelolaan }
$$

dan pengimplementasian Dana Desa di Tingkat desa terdiri dari: Kepala Desa, Sekretaris desa, Kepala urusan perencanaan dan lima bagian perangkat desa diantaranya yaitu bagian pemerintahan, bagian pembangunan, bagian kemasyarakatan, bagian pelayanan umum, dan bagian keuangan, Lembaga Kemasyarakatan, Ketua Dukuh dari setiap Padukuhan.

Perangkat desa yang terdiri dari Kepala desa, Sekretaris Desa bersama kepala urusan dan lima kepala bagian serta dukuh memiliki tanggung jawab sesuai tugasnya masing-masing. Tetapi mengenai penggunaan dana desa lebih dititikberatkan pada bagian pembangunan dan keuangan. Karena pada dasarnya dana desa diperuntukkan untuk pembangunan desa jika dilihat dari prosentase pembagiannya yaitu $70 \%$ : $\quad 30 \%$. $\quad 70 \%$ untuk pembangunan dan $30 \%$ untuk operasional penyelenggaraan pemerintahan desa. Serta bagian keuangan yang mengelola dana desa hal ini karena pemerintahan 
desa wukirsari menganut prosedur keuangan yang bersifat satu pintu. Dimana mengenai pemasukan, pengeluaran dan pencairan dari dana desa sepenuhnya diserahkan oleh bagian keuangan.

b. Masyarakat

Masyarakat terdiri dari perwakilan tiap dukuh yang ada di Desa Wukirari. Masyarakat dalam hal ini sebagai pelaku sekaligus objek dalam pengelolaan dana desa. Selain menyampaikan aspirasinya, masyarakat juga berhak untuk mengelola dana desa serta mengawasi bagaimana pelaksanaan dari implementasi dana desa.

c. BPD (Badan Permusywaratan Desa)

Dalam menjalankan fungsinya sebagai kepala desa, kepala desa berkoordinasi dengan BPD (Badan Permusyawaratn Desa) yang berkedudukan sama dalam struktur organisasi. Fungsi dari BPD sendiri dalam UU No 6 tahun 2014 yaitu menampung dan menyalurkan aspirasi masyarakat desa serta mengawasi kinerja pemerintahan desa. Sebagai bentuk penyelenggaraan dari fungsinya, maka BPD berhak menyelenggarakan musdes untuk mendengar pendapat dari masyarakat terkait pembangunan, kondisi masyarakat desa, kebijakan serta kehendak dari masyarakat desa. Yang kemudian dituangkan dalam RPJMDes.

d. LPMD

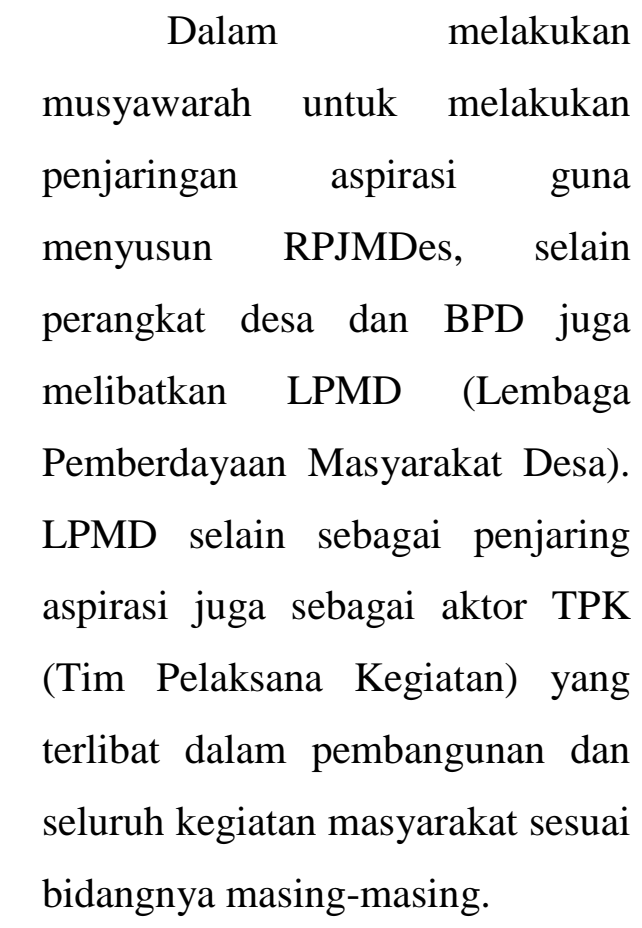

e. TPK (Tim Pelaksana Kegiatan)

Untuk pelaksanaan RKP dan APBDes diperlukan adanya TPK. TPK terdiri dari seluruh perangkat dan lembaga desa. Tergantung pada bentuk kegiatannya. Misal pada kegiatan pembangunan fisik maka dilibatkan dari LPMD bagian Prasarana Fisik, kegiatan karang taruna dengan melibatkan 
LPMD bagian Pemuda dan Olahraga. Namun meskipun tanggung jawab masing masing stakeholder seimbang, masih terdapat peran yang menonjol dalam implementasi penggunaan dana desa yaitu peran dari Sekdes, Kades dan Kepala Bagian Pembangunan. Karena stakeholder tersebut berkaitan erat mengenai tugas dan fungsinya terhadap penggunaan ataupun pengelolaan dana desa. Keterlibatan masyarakat dalam proses penggunaan dana desa hanya terbatas pada proses perencanaan dan penyusunan. Meskipun pada proses pelaksanaan atau implementasi masyarakat juga terlibat namun belum dapat dikatakan sepenuhnya.

\section{Disposisi}

Implementasi dari dana desa dalam prakteknya telah sesuai dengan harapan serta arah kebijakan yang direncanakan oleh pemerintah desa wukirsari, yaitu difokuskan pada perbaikan sarana prasarana atau infrastruktur desa. Namun demikian hal ini kurang sesuai dengan apa yang diharapkan oleh pemerintah pusat ataupun daerah. Implementasi dana desa wukirsari lebih difokuskan pada pembangunan sarana prasarana desa dan hanya berapa persen saja untuk pemberdayaan masyarakat mengingat Desa sudah terlebih dahulu memiliki asset budidaya ikan yang sudah lama dijadikan program pemberdayaan di wukirsari.

Berdasarkan tingkat keterserapannya, dana desa wukirsari hampir terserap sebanyak $100 \%$. Apabila terdapat dana yang tidak terserap, biasanya diakibatkan oleh faktor-faktor yang berkaitan dengan hal-hal teknis dalam pelaksanaannya di lapangan. Apabila terdapat dana yang tidak terserap nantinya akan dikembalikan kepada pemerintah pusat.

Implementasi penggunaan dana desa wukirsari pada dasarnya telah sesuai dengan agenda yang ditetapkan dalam RPJM Desa dan RKP Desa yang ada. Hanya saja dalam teknis pelaksanaannya di lapangan terkadang mengalami sedikit perubahan, seperti terkait waktu pelaksanaan, alokasi dana, dsb. Hal ini dikarenakan oleh sejumlah hal, diantaranya seperti permasalahan administratif yang belum selesai, kondisi di lapangan, kondisi musim, dan lain sebagainya.

Pelaksanaan kegiatan penggunaan dana desa pada bidang pembangunanya 
desa Wukirsari melibatkan langsung masyarakat setempat yang bersistem Gotong Royong. Sehingga pengaruh yang dirasakan oleh masyarakat dari adanya dana desa menjadi semakin signifikan. Prioritas pembangunan yang diarahkan untuk pembangunan infrastruktur secara umum lebih cepat dirasakan masyarakat.

\section{Refleksi Teoritis}

Implementasi Dana Desa di Desa Wukirsari memberikan gambaran bahwa Dana Desa memberikan ruang fiskal yang luas bagi pemerintah desa sesuai dengan penelitian World Bank (2015).

Apabila melihat lebih dalam teori George E. Edward (1980) melalui empat aspek yang menentukan keberhasilan implementasi yaitu komunikasi, sumberdaya, struktur birokrasi dan disposisi, program dana desa di Desa Wukirsari cukup berhasil. Walaupun demikian, teori George Edward III (1980) juga mengungkapkan pendekatan topdown yang masih cukup melekat dalam penyelenggaraan kebijakan, seperti yang terjadi di Desa Wukirsari. Pendekatan yang dikatakan top-down atau "fenomena elit berkuasa" ini (Pressman dan Wildavsky, 1973; Van Meter dan Van
Horn, 1975; Edward (1980); Mazmanian dan Sabatier, 1983) terjadi karena posisi pemerintah desa yang kuat akibat relasi patronase (Usman, 2004). Masyarakat secara umum hanya terlibat dalam musyawarah dan memahamami Dana Desa melalui sosialisasi tanpa terlibat langsung. Padahal, pelibatan masyarakat sangat tinggi pada saat dilibatkan sebagai pekerja membangun proyek-proyek desa.

Proses kebijakan menunjukkan bahwa komunikasi internal birokrasi berjalan baik antara Kepala Bagian Keuangan, Badan Pemberdayaan Masyarakat Desa dan Pemerintah Desa (BPD dan Pemdes), Camat Cangkringan Sleman, secara keseluruhan telah berjalan dan terkoordinasi dengan baik. Jika dilihat dari kejelasannya komunikasi yang terjalin dalam mengimplementasikan Dana Desa, Pemerintah Daerah sudah memberikan petunjuk penggunaan Dana Desa (DD) dari Setda Kabupaten Sleman yang dikirimkan Pemdes dan Camat Kec Cangkringan Sleman. Pada petunjuk tersebut sudah tertulis dengan jelas apa saja peranan instansi terkait dan bagaimana seharusnya desa membagi anggaran tersebut sesuai dengan kegunaannya. Namun, dalam proses musyawarah dan sosialisasi, masyarakat hanya menjadi "penonton" karena semua 
rencana telah diatur oleh pemerintah desa dan masyarakan hanya mengikuti saja. Hal ini menyebabkan kurang optimalnya pemahaman dan transparansi kepada masyarakat dalam penggnaan dana desa.

Sumberdaya di Desa Wukirsari meliputi dana dan kapasitas kelembagaan. Pagu dana desa memberikan proporsi yang cukup besar dalam APBDes. Hal ini tentu memberikan stumulus bagi percepatan pembangunan desa.

Pemahaman pegawai pemerintah desa sebagai street level bureaucracy dari dana desa cukup baik walaupun memiliki beragam kualitas pemahaman terhadap dana desa. Disisi lain, kemampuan pegawai hanya terbatas dalam melaksanakan perintah. Pendidikan dan skill yang dimiliki oleh pegawai kurang memenuhi bila dituntut adanya inovasi dalam perbaikan implementasi.

Birokrasi yang bertindak sebagai pelaksana sebuah kebijakan harus dapat mendukung kebijakan yang telah diputuskan secara politik dengan melakukan koordinasi yang baik. Jika diperhatiakan implementasi kebijakan Dana Desa di Kabupaten Sleman terutama di Desa Wukirsari sudah berjalan dengan baik dan sesuai dengan prosedur. Dalam implementasi kebijakan Dana Desa ini petunjuk teknis pengelolaan dana desa bertindak sebagai Standart Operating Prosedure (SOP) yang akan menuntun tahap demi tahap yang harus dilakukan agar kebijakan ini bias terlaksana sesuai sasaran. Koordinasi anatara pemerintah pusat dan pemerintah daerah dengan desa Wukirsari dan desa lainya di Kecamatan cangkringan sleman sudah brjalan baik. Desa wukirsari juga memiliki TPK (Tim Pengelola Kegiatan) yakni setiap program yang sudah direncanakan akan dibantu oleh TPK dalam pelaksanaan dilapangan.

Implementasi dari dana desa dalam prakteknya telah sesuai dengan harapan serta arah kebijakan yang direncanakan oleh pemerintah Desa Wukirsari, yaitu difokuskan pada perbaikan sarana prasarana atau infrastruktur desa. Struktur birokrasi dan adanya TPK membuat disposisi menjadi kuat. Peraturan pengelolaan keuangan yang rigid dan berkonsekuensi hukum menjadi faktor yang mendorong pemerintah Desa Wukirsari taat aturan.

Namun, tuntutan peraturan perundang-undangan untuk meningkatkan pelibatan masyarakat sebesar-besarnya tidak terjadi. Padahal, kebijakan publik yang identik dengan proses birokrasi pemerintah (inward looking), konsep 
partisipasi publik yang banyak dituntut para penganjur demokrasi akan menjadi selogan kosong (Santoso, Hanif dan Gustomy, 2004). Dalam kenyataanya, pemerintah desa hanya melibatkan masyarakat dalam musyawarah desa dan pelibatan sebagai pekerja pada tahap pelaksanaan pembangunan.

Implementasi Dana Desa di Desa Wukirsari tidak dapat menumebus ortodoksi pemerintah seperti pendapat Rozaki (2005). Padahal, peluangnya besar untuk mewujudkan hal tersebut. Weinstein (2008) mengatakan peluang besar bila pembangunan dapat dimulai dari desa. Pemerintah desa juga dapat melakukan kemitraan yang lebih luas baik dengan swasta, masyarakat maupun institusi publik (Beamount dan Nicholls, 2008). Namun, di Desa Wukirsari yang terjadi sebaliknya, masyarakat pasif terhadap program. Modal sosial yang dapat meningkatkan pembangunan lokal (Asni et. al, 2013) tidak dapat dimanfaatkan dengan baik. Bila merujuk pada Warsono dan Ruksamin (2014), terdapat tiga hambatan-hambatan dalam implementasi yaitu 1) pendidikan masyarakat yang rendah, 2) kemampuan manajerial yang rendah dari desa dan institusi pendukung lainnya, 3) kegagalan mekanisme dari sosialisasi.

\section{SIMPULAN}

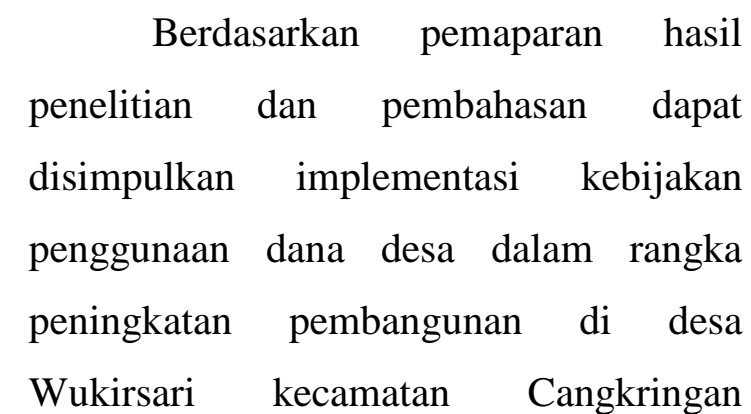
Kabupaten Sleman terlaksana dengan baik sesuai dengan tujuan kebijakan. Keberhasilan program tersebut dapat dilihat pada produk pembangunan yang telah selesai dilaksanakan dengan menggunakan dana desa secara $100 \%$. Beberapa faktor yang mempengaruhi faktor keberhasilan implementasi kebijakan tersebut adalah sebagai berikut:

1. Faktor komunikasi dalam Proses implementasi kebijakan yang baik. Telah terjadi komunikasi internal birokrasi yang baik antara Kepala Bagian Keuangan, Badan Pemberdayaan Masyarakat Desa dan Pemerintah Desa (BPD dan Pemdes), Camat Cangkringan Sleman, sehingga terdapat kepahaman, kejelasan dan kesamaan persepsi terhadap implementasi kebijakan secara baik dan benar.

2. Tingkat kecukupan Sumberdaya yang dimiliki pemerintah desa Wukirsari, baik berupa 
sumberdaya dana maupun kapasitas kelembagaan dalam melaksanakan kebijakan penggunaan dana desa.

3. Struktur Birokrasi yang memiliki rincian tugas yang jelas dengan dilengkapi Standart Operating Prosedure (SOP), dan sistem koordinasi yang baik antara pemerintah pusat dan pemerintah daerah dengan desa Wukirsari dan desa lainya.

4. Faktor disposisi yakni sikap implementor dalam kebijakan penggunaan dana desa di desa Wukirsari sangat bagus. Terdapat komitment yang tinggi dalam pelaksanaan pembangunan

\section{DAFTAR PUSTAKA}

Asni, et. al. 2013. The Management of the Village Fund Allocation as an Instrument towards Economic Independence Village. IOSR Journal of Business and Management

Beaumont, J. and Nicholls, W. 2008. Plural Governance, Participation and Democracy in Cities, International Journal of Urban and Regional Research, 32, pp. 87-94.

Creswell, J. W. 2010. Research Design Pendekatan Kualitatif, Kuantitatif, dan Mixed. Yogyakarya: Pustaka Pelajar.
Edward III, George C. 1980. Implementing Public Policy. Washington: Congressional. Quartely Press

Hehamahua, Hayati. 2015. Impact Analysis of the Village Fund Allocation (ADD) Toward Economic Community (Case Study on the Rural District of Namlea Siahoni), Buru Regency. Journal of Social and Development Sciences (ISSN 2221-1152) Vol. 6, No. 3, pp. 15-23.

Ife, J \& Tesoriero, F. 2008. Community Development: Alternatif Pengembangan Masyarakat di Era Globalisasi. Yogyakarta: Pustaka Pelajar

Mazmanian, Daniel H dan Sabatier, Paul. 1983. Implementation and Public Policy. New York: HarperCollins.

Miles, B. B dan Huberman, A. M. 1992. Analisa Data Kualitatif. Jakarta: UI Press

Moleong, Lexy J. 2004. Metodologi Penelitian Kualitatif. Bandung: Remaja Rosdakarya.

Pressman, J. L dan Wildavsky, A. 1973. Implementation: How Great Expectation in Washington are Dased in Oakland. London: California Press.

Rozaki, Abdur, dkk. (2005). Prakarsa Desentralisasi dan Otonomi Desa. Yogyakarta, IRE Press.

Santoso, P., Hanif, H., dan Gustomy, R. 2004. Menembus Ortodoksi Kajian Kebijakan Publik. Yogyakarta: Fisipol UGM

Soetrisno, L. (1988). Negara dan Peranannya dalam Menentukan Pembangunan Desa yang Mandiri. 
Prisma No. 1 Tahun XVII Januari 1988. Jakarta

Strauss, A. dan Corbin, J. 2007. DasarDasar Penelitian Kualitatif. Yogyakarta: Pustaka Pelajar.

Sutopo, H.B. 2002. Metodologi Penelitian Kualitatif. Surakarta: UNS Press

Usman, Sunyoto. 2004. Sosiologi; Sejarah, Teori dan Metodologi. Yogyakarta: Center for Indonesian Research and Development [CIReD].

Van Meter, Donald dan Van Horn, Carl. 1975, The Policy Implementation Process: A Conceptual Framework. Administration and Society 6 . London: Sage.

Wahab, Solichin Abdul. 2008. Analisis Kebijakan: Dari Formulasi Ke Implementasi Kebijaksanaan Negara. Jakarta: BumiAksara.

Warsono, $\mathrm{H}$ dan Ruksamin. 2014. The Obstacles of Implementation of Village Allocation Fund Program in the North Konawe Southeast Sulawesi. Journal of Management and Sustainability.

Wetzstein, S. 2008. Relaunching Regional Economic-Development Policy and Planning for Auckland: Remaking The State and Contingent Governance Under Neoliberalism, Environment and Planning C, 26, pp. 1093-1112.

Widodo, Joko. 2009. Analisis Kebijakan Publik: Konsep dan Aplikasi Analisis Proses Kebijakan Publik. Malang: Bayumedia.
Winarno, Budi. 2002. Teori \& Proses Kebijakan Publik. Yogya: Med Press.

World Bank. 2015. Country Summary Brief: Indonesia. World Bank Group for Social, Urban, Rural and Resilience.

Yin, R K. 2003. Studi Kasus: Disain dan Metode. Terj. M. Djauzi Mudjakir. Jakarta: PT. Raja Grafindo Persada. 